\title{
Simultaneous determination of methylcarbamate and ethylcarbamate in fermented foods and beverages by derivatization and GC-MS analysis
}

Ho-Sang Shin ${ }^{1 *}$ and Eun-Young Yang ${ }^{2}$

\begin{abstract}
Background: Methylcarbamate $(\mathrm{MC})$ and ethylcarbamate (EC) are toxic compounds that commonly exist in fermented food and beverages. In order to estimate the risk for their exposure, a sensitive simultaneous analytical method is required

Results: A simultaneous determination of $M C$ and EC was described based on derivatization with 9-xanthydrol and consecutive detection using gas chromatography-mass spectrometry. The derivatization of $\mathrm{MC}$ and EC was performed directly in food or beverages and the reaction conditions were established through changing various parameters. The detection and the quantification limits were $0.01-0.03 \mu \mathrm{g} / \mathrm{kg}$ and $0.03-0.1 \mu \mathrm{g} / \mathrm{kg}$, respectively, and the interday relative standard deviation was less than $12 \%$ at concentrations of 2.0 and $50 \mu \mathrm{g} / \mathrm{kg}$. MC and EC were measured from $0.4 \mu \mathrm{g} / \mathrm{kg}$ to $85.8 \mu \mathrm{g} / \mathrm{kg}$ in sixteen Korean fermented foods and eleven beverages.

Conclusion: A simple, sensitive method to detect MC and EC in several solid foods and liquid foods was developed based on derivatization with 9-xanthydrol for $10 \mathrm{~min}$ at an ambient temperature. The method may useful for routine analysis of $M C$ and EC in numerous food samples.
\end{abstract}

Keywords: Methylcarbamate, Ethylcarbamate, Fermented food, Beverages, GC-MS

\section{Background}

Ethylcarbamate (EC, urethane, $\mathrm{C}_{2} \mathrm{H}_{5} \mathrm{OCONH}_{2}$ ) is a known genotoxic carcinogen that commonly exists in fermented food and beverages due to the natural biochemical processes in the fermentation process [1,2]. EC was re-classified as a carcinogen (Group 2A) by the International Agency for Research on Cancer (IARC) in 2007 [3] and has already been regulated in several countries such as Germany, USA, Canada, France and the Czech Republic [2]. A report from a commission by the European Food Safety Authority (EFSA) issued in 2010 [4] recommended that special attention should be paid to spirits distilled from stone fruits. Furthermore, EC has been detected in various fermented products such as bread, yoghurt, cheese, soy sauce, vinegar and alcoholic beverages $[5,6]$.

Methylcarbamate (MC, methylurethane, $\mathrm{CH}_{3} \mathrm{OCONH}_{2}$ ) is simplest ester of carbamic acid. MC has a relatively low

\footnotetext{
* Correspondence: hshin@kongju.ac.kr

'Department of Environmental Education, Kongju 314-701, Republic of Korea Full list of author information is available at the end of the article
}

toxicity, otherwise, there is experimental evidence that $\mathrm{MC}$ is mutagenic in Droso phila [7] and carcinogenic in rats [8].

EC and MC can co-exist through natural formation during the fermentation processes [9]. In order to estimate the risk for EC and MC exposure, a sensitive simultaneous analytical method in fermented foods and beverages is required.

Many methods for detecting EC in beverages have been reported, such as high-performance liquid chromatography (HPLC) [10-12], liquid chromatography tandem mass spectrometry (LC-MS/MS) [13], gas chromatography (GC) [14-17], and gas chromatography mass spectrometry (GC-MS) [6,9,18-27].

Several assay methods have been based on headspace solid-phase micro extraction (HS-SPME) [14,15,22,28], where the headspace is discriminatory in nature because only the volatile compounds in the injection vials can be transferred to the GC system. Many volatile alcohols and interferences exist in fermented food and beverages, give much interference, and have a short fiber life time. 
Liquid-liquid extraction (LLE) $[16,19,21]$ and solid phase extraction (SPE) $[20,21,26]$ are often used to determine the EC content in alcoholic beverages. Although it is a traditional extraction technique, LLE represents a convenient method when it is connected with derivatization. Also, 9-xanthydrol has been used to improve the fluorescence of EC in the HPLC method [10-12] and to improve the sensitivity of EC using the GC-MS [21]. However, until now, analytical target compounds and matrices were limited to EC and liquid phases such as spirits or beverages. Another drawback with the methods is that EC is derivatized using 9-xanthydrol after extraction and concentration, and in this case volatile $\mathrm{MC}$ and EC can be lost during the evaporation process.

GC coupled with mass spectrometry (GC-MS) is the most widely used due to its good resolution, sensitivity and selectivity. Although the GC-MS methods are very selective and sensitive, it is difficult to detect to $\mathrm{ng} / \mathrm{kg}$ levels without concentration and derivatization.

In this study, the derivatization parameters that enable the direct reaction of $\mathrm{MC}$ and $\mathrm{EC}$ in food or beverages are established. The xanthyl methylcarbamate or xanthyl ethylcarbamate derivatives that were formed were extracted by LLE and detected by GC-MS. Therefore, the experiment reported in this paper aimed to optimize the parameters of the derivatization, extraction and GCMS detection in order to simultaneously determine the $\mathrm{MC}$ and EC in fermented foods and beverages, and in order to apply the modified method in the analysis of seventeen real samples.

\section{Experimental}

\section{Materials}

All organic solvents used were HPLC grade. Sodium chloride, potassium hydroxide, sodium bicarbonate, potassium carbonate, propanol, ethyl acetate, sodium sulfate, 9-xanthydrol (99\%), methylcarbamate (98\%), ethylcarbamate (EC, $99 \%)$, and butylcarbamate (98\%) as internal standard were obtained from Sigma-Aldrich (St. Louis, MO, USA).

\section{Apparatus}

All mass spectra were obtained with an Agilent 6891/ 5973N instrument (Agilent Technologies, Santa Clara, CA, USA). The ion source was operated in the electron ionization mode (EI; $70 \mathrm{eV})$. Full-scan mass spectra $(\mathrm{m} / \mathrm{z}$ 45-600) were recorded in order to identify the analytes. An HP-5MS capillary column $(60 \mathrm{~m} \times 0.25 \mathrm{~mm}$ I.D. $\times$ $0.25 \mu \mathrm{m}$ film thickness) was used. The samples were injected in the splitless mode. The flow rate of helium as a carrier gas was $0.6 \mathrm{~mL} / \mathrm{min}$. The injector temperature was set at $260^{\circ} \mathrm{C}$. The oven temperature programs were set as follows. The initial temperature of $150^{\circ} \mathrm{C}$ was not held and increased to the first temperature hold of $210^{\circ} \mathrm{C}$ (held for $1 \mathrm{~min}$ ) at $30^{\circ} \mathrm{C} / \mathrm{min}$, and then increased to the final temperature hold of $260^{\circ} \mathrm{C}$ (held for $4 \mathrm{~min}$ ) at $10^{\circ} \mathrm{C} / \mathrm{min}$. The ions selected by SIM were $\mathrm{m} / \mathrm{z} 222,240$ and 255 for xanthyl methylcarbamate, $\mathrm{m} / \mathrm{z} \quad 222,240$ and 269 for xanthyl ethylcarbamate and $\mathrm{m} / \mathrm{z} 222,240$ and 297 for xanthyl butylcarbamate.

\section{Derivatization and extraction procedures}

Fermented foods (soybean paste, red pepper paste and soy sauce) were purchased from several local markets or obtained from several homes. Beverages containing makgeolli (raw rice wine), soju (white distilled liquor), jeongjong (refined rice wine) and fruit liquor were purchased from several local markets.

A 2.0 g portion of each sample was homogenized for $10 \mathrm{~min}$ at $18,000 \mathrm{rpm}$ in $5.0 \mathrm{~mL}$ of $\mathrm{NaCl}$ saturated solution using a homogenizer (PowerGen 125, Fisher Scientific, USA) after adding $80 \mu \mathrm{L}$ of $0.1 \mathrm{M}$ 9-xanthydrol solution in the propanol, $200 \mu \mathrm{L}$ of $2.0 \mathrm{M} \mathrm{HCl}$, and 20 $\mu \mathrm{L}$ of $\mathrm{BC}(2.5 \mathrm{mg} / \mathrm{L}$ in methanol). The derivatization reaction was conducted at an ambient temperature for 10 min in the dark, and then the solution was neutralized with $1.0 \mathrm{M} \mathrm{KOH}$ and the $\mathrm{pH}$ of the solution was controlled to 9.5 with $0.2 \mathrm{~g}$ of $\mathrm{NaHCO}_{3} / \mathrm{K}_{2} \mathrm{CO}_{3}(2: 1, \mathrm{w} / \mathrm{w})$. The solution was extracted twice with $5.0 \mathrm{~mL}$ of ethyl acetate. The organic layers were combined and dried by passing them through anhydrous sodium sulfate. The dried organic layer was then concentrated in a rotary<smiles>[R]OC(=O)NC1c2ccccc2Oc2ccc(CC)cc21</smiles>

Alkyl carbamate 9-Xanthydrol

Xanthyl alkyl carbamate

$\left(\mathrm{R}=\mathrm{CH}_{3}, \mathrm{C}_{2} \mathrm{H}_{5}\right.$ or $\left.\mathrm{C}_{4} \mathrm{H}_{9}\right)$

Figure 1 The reaction of alkyl carbamates with 9-xanthydrol. 


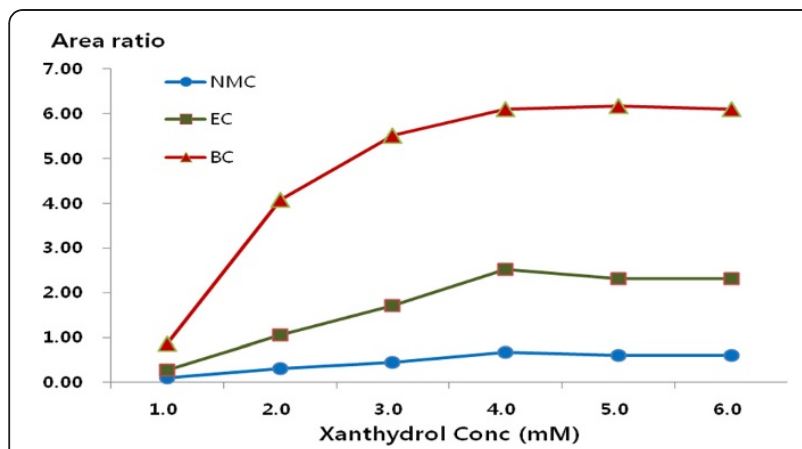

Figure 2 Reaction yield of $M C, E C$ and $B C$ in relation to the amount of 9-xanthydrol. (This experiment was performed at a reaction time of $10 \mathrm{~min}$ and a reaction temperature of $20^{\circ} \mathrm{C}$ ).

evaporator $\left(30^{\circ} \mathrm{C}, 300 \mathrm{mbar}\right)$. The concentrated residue was dissolved in $100 \mu \mathrm{L}$ of methanol and a $1.0 \mu \mathrm{L}$ sample of the solution was injected into the GC-MS system.

The derivatization efficiencies were calculated at various temperatures $\left(20,30,40\right.$, and $\left.50^{\circ} \mathrm{C}\right)$, 9-xanthydrol amounts $(20,40,60,80,100$, and $120 \mu \mathrm{L}$ of $0.1 \mathrm{M}$ solution), heating times $(5,10,15,20,30$ and $60 \mathrm{~min})$, and acid moralities $(0.1,0.2,0.3,0.4,0.5$ and $1.0 \mathrm{M})$. The $\mathrm{pH}$ of each sample was controlled with $2.0 \mathrm{M} \mathrm{HCl}$. The optimum derivatization conditions of $\mathrm{MC}, \mathrm{EC}$ and $\mathrm{BC}$ with 9-xanthydrol were determined using the amounts of the formed xanthyl methylcarbamate, xanthyl ethylcarbamate and xanthyl butylcarbamate.

\section{Calibration and quantification}

The calibration curves for MC and EC were established through derivatizations after 1.0, 5.0, 20, 50, 100 and 200 ng of MC and EC standard solutions were added to $2.0 \mathrm{~g}$ of a control food (soybean paste), $5 \mathrm{~mL}$ of $\mathrm{NaCl}$ saturated solution, $20 \mu \mathrm{L}$ of $\mathrm{BC}(2.5 \mathrm{mg} / \mathrm{L}$ in methanol), $80 \mu \mathrm{L}$ of $0.1 \mathrm{M} 9$-xanthydrol solution in propanol and $200 \mu \mathrm{L}$ of $2.0 \mathrm{M} \mathrm{HCl}$. The corresponding concentrations of the standards were $0.5,2.5,10,25,50$ and $100 \mu \mathrm{g} / \mathrm{kg}$. The ions selected for quantification were $\mathrm{m} / \mathrm{z} 255$ for

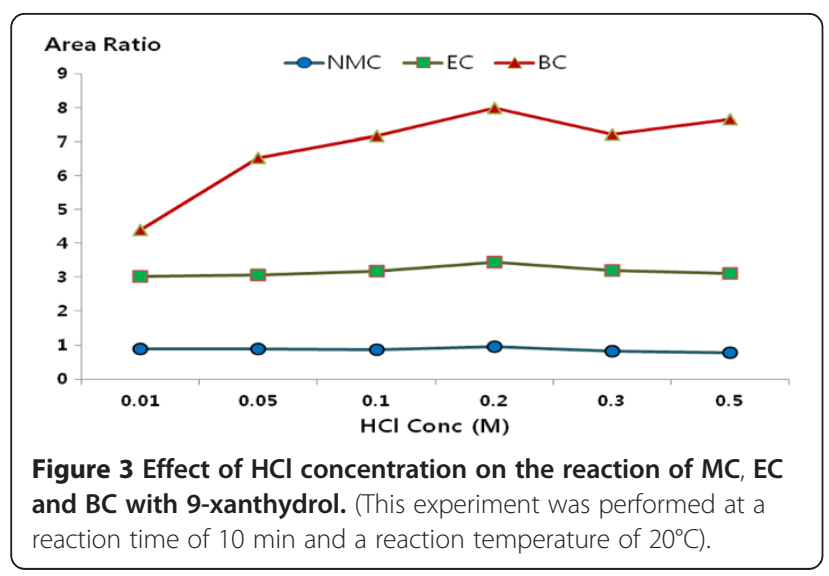

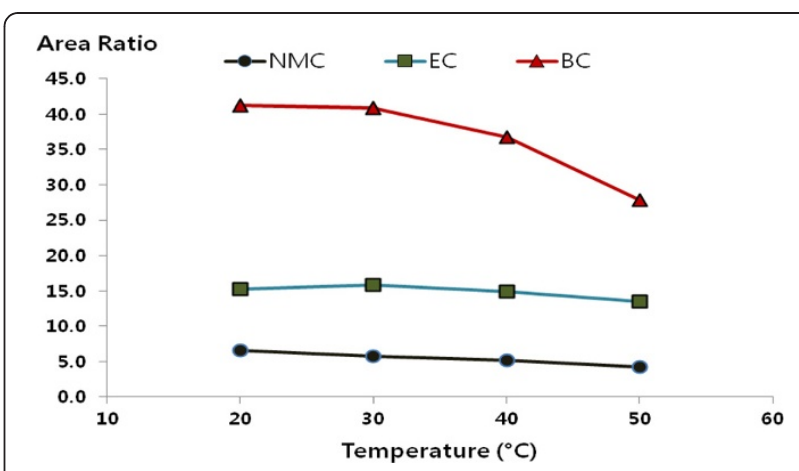

Figure 4 Effect of reaction temperature on the reaction of MC, EC and BC with 9-xanthydrol. (This experiment was performed at a reaction time of $5 \mathrm{~min}$ ).

xanthyl methylcarbamate, and $\mathrm{m} / \mathrm{z} 240$ for xanthyl ethylcarbamate and xanthyl butylcarbamate. The ratio of the peak area of the standard solution to that of the internal standard was used to quantify the compound.

\section{Results and discussion}

Optimization of the derivatization conditions in samples

The amino groups of $\mathrm{MC}, \mathrm{EC}$, and $\mathrm{BC}$ undertook the substitution reaction with 9-xanthydrol under acidic conditions in order to produce xanthyl methylcarbamate, xanthyl ethylcarbamate, and xanthyl butylcarbamate as shown in Figure 1, and it was possible to directly analyze the product by the GC-MS.

The optimal reaction conditions for the simultaneous determination of MC and EC in solid fermented foods was also tested. For the first test, the minimum amount of 9-xanthydrol for the derivatization was studied. The derivatization was performed for various 9-xanthydrol concentrations $(1.0,2.0,3.0,4.0,5.0$ and $6.0 \mathrm{mM}$ of 9 xanthydrol). The yield stayed continuously beyond 4.0 $\mathrm{mM}$ of 9-xanthydrol and the optimal 9-xanthydrol amount was $4.0 \mathrm{mM}$ (Figure 2). The effect of the acid concentration on the reaction of $\mathrm{MC}, \mathrm{EC}$ and $\mathrm{BC}$ with 9-xanthydrol was also studied. The derivative was tested

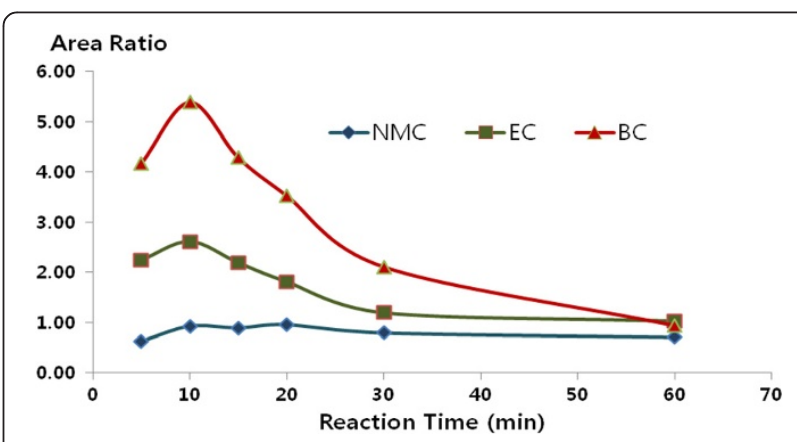

Figure 5 Effect of reaction time on the reaction of MC, EC and BC with 9-xanthydrol. (This experiment was performed at a reaction temperature of $20^{\circ} \mathrm{C}$ ). 


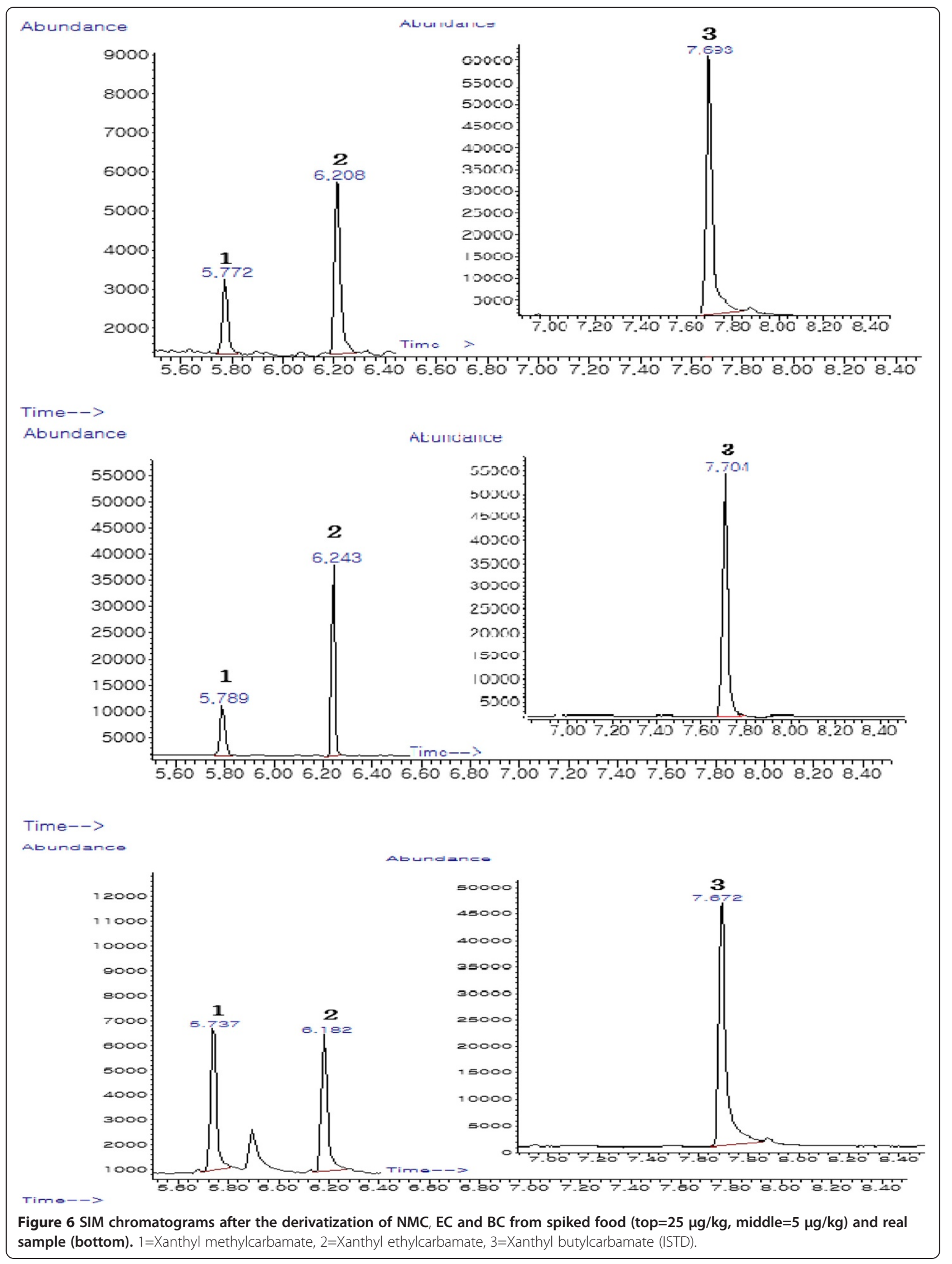




\section{(a) Xanthyl methylcarbamate}

Abundance

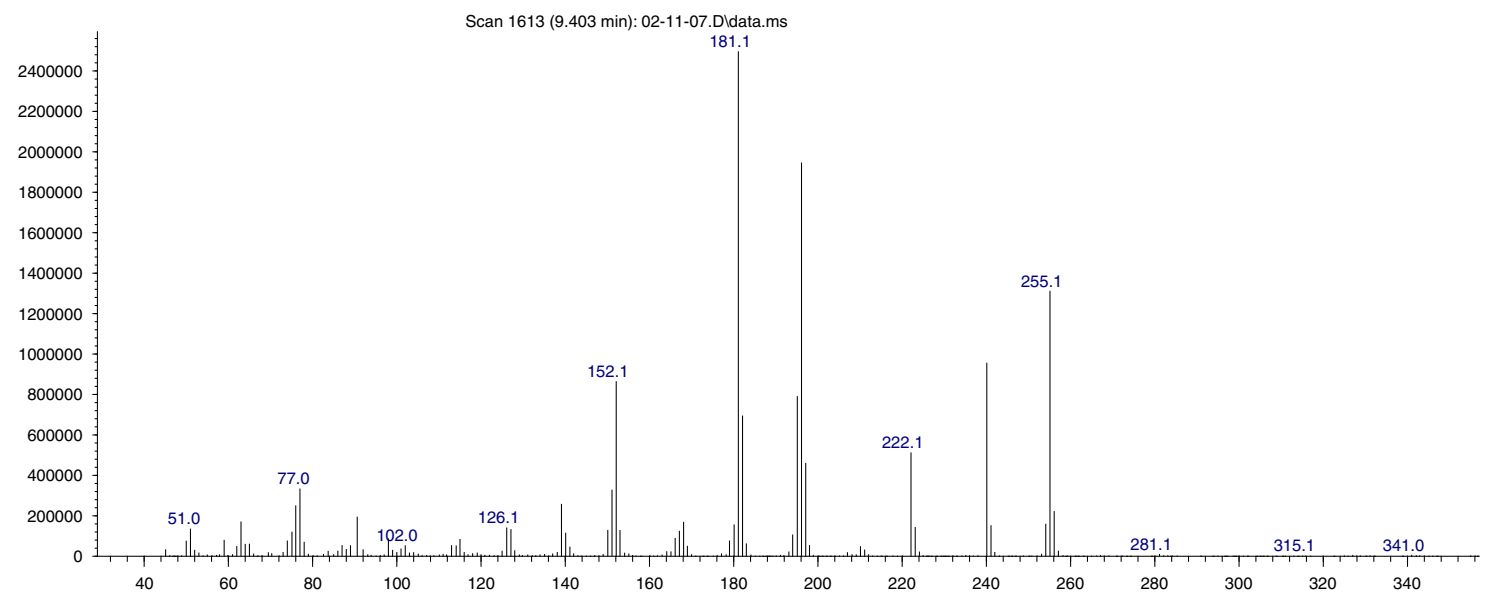

(b) Xanthyl ethylcarbamate

Ab u ndance

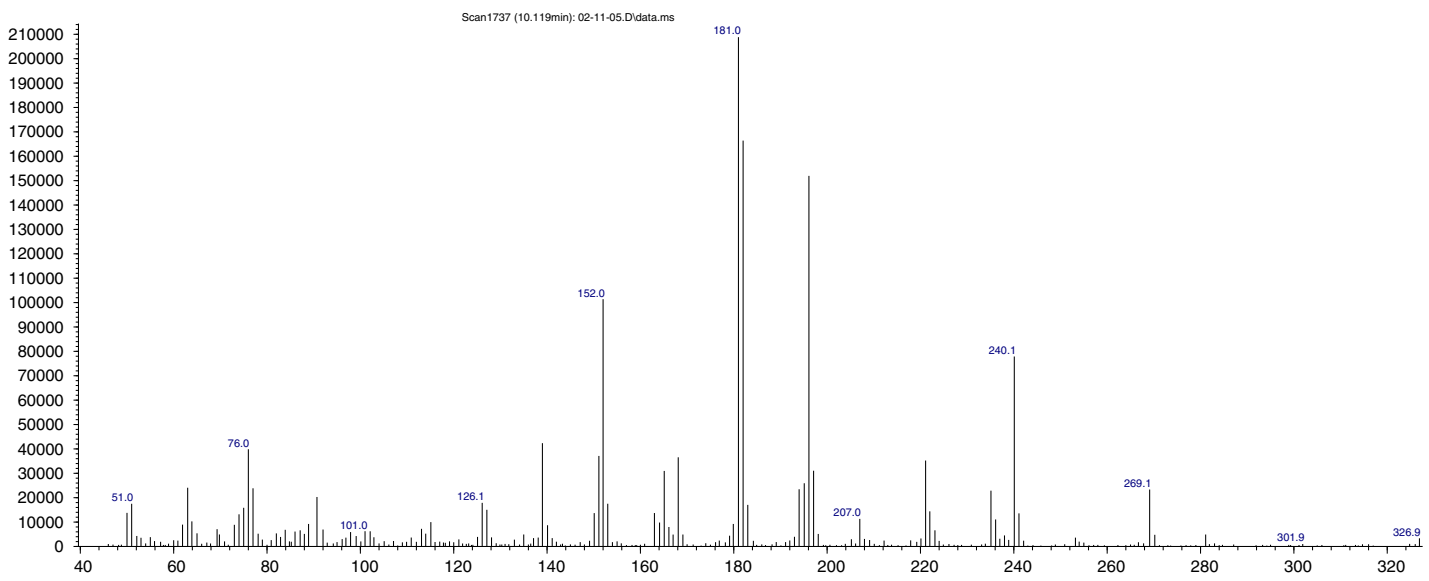

(C) Xanthyl butylcarbamate

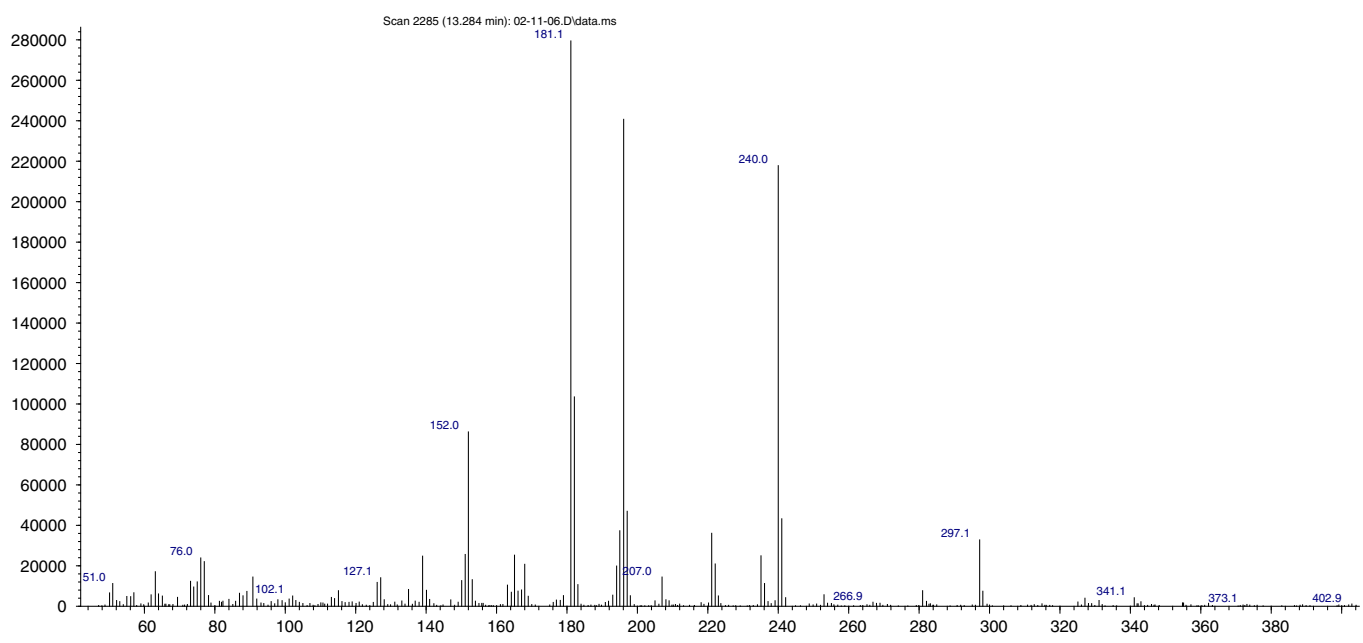

Figure 7 Mass spectra of xanthyl methylcarbamate, xanthyl ethylcarbamate and xanthyl butylcarbamate. 
Table 1 Comparison of analytical methods for determining of NMC and EC in fermented food

\begin{tabular}{|c|c|c|c|c|c|c|c|c|}
\hline \multirow[t]{2}{*}{ Reference } & \multirow[t]{2}{*}{ Matrix } & \multirow{2}{*}{$\begin{array}{l}\text { Preparation } \\
\text { method }\end{array}$} & \multirow[t]{2}{*}{ Derivatization } & \multirow[t]{2}{*}{ Measurement } & \multicolumn{2}{|c|}{$\operatorname{LOD}(\mu \mathrm{g} / \mathrm{L}$ or $\mu \mathrm{g} / \mathrm{kg})$} & \multicolumn{2}{|c|}{$\mathrm{LOQ}(\mu \mathrm{g} / \mathrm{L}$ or $\mu \mathrm{g} / \mathrm{kg})$} \\
\hline & & & & & MC & EC & MC & EC \\
\hline$[10]$ & Alcoholic beverage & - & 9-xanthydrol & HPLC-FLD & & $3.0-$ & - & - \\
\hline [11] & Wine & - & 9-xanthydrol & HPLC-FLD & - & $73.2-$ & - & $243.9-$ \\
\hline [12] & Cider spirits & - & 9-xanthydrol & HPLC-FLD & - & 1.64 & - & 3.56 \\
\hline \multirow[t]{2}{*}{ [13] } & Ethanol solution & - & - & LC-MS/MS & & 2.0 & - & 5.1 \\
\hline & Palinka spirits & & & LC-MS/MS & & 2.8 & - & 8.0 \\
\hline [15] & Alcoholic beverage & HS-SPME & - & GC-NPD & - & 34 & - & - \\
\hline [19] & Alcoholic beverage & LLE & - & GC-MS & - & 2.3 & - & 10.4 \\
\hline$[20]$ & Fermented food & SPE & - & GC-HRMS & - & 0.03 & - & 0.05 \\
\hline$[22]$ & Stone-fruit spirits & HS-SPME & - & GC-MS/MS & - & 0.03 & - & 0.11 \\
\hline [21] & Stone-fruit spirits & SPE & - & GC-MS/MS & - & 0.01 & - & 0.04 \\
\hline [27] & Italian aqua vitae & LLE & 9-xanthydrol & GC-MS & - & 1.0 & - & - \\
\hline This study & Fermented food and beverage & LLE & 9-xanthydrol & GC-MS & 0.11 & 0.12 & 0.33 & 0.38 \\
\hline
\end{tabular}

at $\mathrm{HCl}$ concentrations of $0.01,0.05,0.1,0.2,0.3$, and $0.5 \mathrm{M}$. The other reaction conditions were set to have a reaction time of $10 \mathrm{~min}$ at a temperature of $20^{\circ} \mathrm{C}$. The results showed good recovery at the $\mathrm{HCl}$ concentration value of $0.2 \mathrm{M}$ (Figure 3). The reaction rate of $\mathrm{MC}, \mathrm{EC}$ and $\mathrm{BC}$ with 9-xanthydrol was also studied. The reaction rate of the derivative was analyzed at reaction temperatures of 20,30 , 40 , and $50^{\circ} \mathrm{C}$ and the reaction time was analyzed in at 5 , 10, 20, 30, and $60 \mathrm{~min}$. From the experiment, the optimal reaction temperature and time was $10 \mathrm{~min}$ at $20^{\circ} \mathrm{C}$ (Figures 4 and 5 ). The recovery was declined slowly beyond the reaction time of $10 \mathrm{~min}$.

As a result, the optimal reaction conditions of MC, $\mathrm{EC}$, and $\mathrm{BC}$ with 9-xanthydrol were $4.0 \mathrm{mM}$ 9-xanthydrol, $0.2 \mathrm{M} \mathrm{HCl}$ concentration, the reaction time of 10 min at an ambient temperature.

The selection of the extraction solvent was of great importance in order to achieve satisfactory extraction efficiency for the target compounds. Based on the consideration for the solvent strength, methylene chloride, ethyl acetate, ethyl ether and hexane were selected as potential extraction solvents for use in this study. As a result, ethyl acetate gave the highest extraction efficiency, and ethyl acetate was selected as an extraction solvent of the analyte derivatives from samples.

\section{Chromatography and mass spectrometry}

The optimum derivatization conditions were applied to the analysis of $\mathrm{MC}, \mathrm{EC}$, and $\mathrm{BC}$ in fermented food and beverages by GC-MS. Figure 6 shows the GC-MS chromatogram after the derivatization of $\mathrm{MC}, \mathrm{EC}$, and $\mathrm{BC}$. For the GC separation of the derivative, the use of a nonpolar stationary phase was found to be efficient. The derivatives of $\mathrm{MC}, \mathrm{EC}$, and $\mathrm{BC}$ showed a sharp peak, and the compound was quantified as an integration of the peak area. The retention times of xanthyl methylcarbamate, xanthyl ethylcarbamate and xanthyl butylcarbamate are shown in Figure 6. Extraneous peaks were not observed in the chromatograms near the retention times of the analytes.

The mass spectra of xanthyl methylcarbamate, xanthyl ethylcarbamate and xanthyl butylcarbamate by electron ionization at $70 \mathrm{eV}$ have similar fragmentation pattern as shown in Figure 7. The molecular ions at $\mathrm{m} / \mathrm{z} 255, \mathrm{~m} / \mathrm{z}$ 269 and $\mathrm{m} / \mathrm{z} 297$ were appeared in mass spectra of three compounds. The fragment of $\mathrm{m} / \mathrm{z} 240$ was accounted for by the loss of $\left[\mathrm{CH}_{3}\right],\left[\mathrm{C}_{2} \mathrm{H}_{5}\right]$ and $\left[\mathrm{C}_{4} \mathrm{H}_{9}\right]$ from the each molecular ion and that of $\mathrm{m} / \mathrm{z} 196$ was accounted for by the loss of $\left[\mathrm{COOCH}_{3}\right],\left[\mathrm{COOC}_{2} \mathrm{H}_{5}\right]$ and $\left[\mathrm{COOC}_{4} \mathrm{H}_{9}\right]$, and $\mathrm{m} / \mathrm{z} 222$ were accounted for by the loss of $\left[\mathrm{H}_{2} \mathrm{OCH}_{3}\right],\left[\mathrm{H}_{2} \mathrm{OC}_{2} \mathrm{H}_{5}\right]$ and $\left[\mathrm{H}_{2} \mathrm{OC}_{4} \mathrm{H}_{9}\right]$ from the each

Table 2 Intraday and interday laboratory precision and accuracy results for the analysis of NMC and EC in fermented food $(n=5)$

\begin{tabular}{|c|c|c|c|c|c|c|c|}
\hline \multirow[t]{2}{*}{ Compound } & \multirow{2}{*}{$\begin{array}{l}\text { Spiked Conc. } \\
\text { (mg/L) }\end{array}$} & \multicolumn{3}{|c|}{ Intraday measured value } & \multicolumn{3}{|c|}{ Interday measured value } \\
\hline & & Mean \pm SD (mg/L) & Accuracy (\%) & Precision (\%) & Mean \pm SD (mg/L) & Accuracy (\%) & Precision (\%) \\
\hline \multirow[t]{2}{*}{ NMC } & 0.0500 & $0.0492 \pm 0.0031$ & 98.4 & 6.30 & $0.0474 \pm 0.0052$ & 94.8 & 11.0 \\
\hline & 0.0020 & $0.0018 \pm 0.0002$ & 90.0 & 11.1 & $0.0017 \pm 0.0002$ & 106 & 11.8 \\
\hline \multirow[t]{2}{*}{ EC } & 0.0500 & $0.0532 \pm 0.0030$ & 106 & 5.64 & $0.0546 \pm 0.0065$ & 109 & 11.9 \\
\hline & 0.0020 & $0.0018 \pm 0.0002$ & 90.0 & 11.1 & $0.0019 \pm 0.0002$ & 95.0 & 10.5 \\
\hline
\end{tabular}


molecular ion. The fragment of $\mathrm{m} / \mathrm{z} 181$ was a result of the xanthyl group.

\section{Validation of the assay}

The combination of a high derivatization yield and the high sensitivity of the derivative by EI-MS (SIM) allowed the detection of $\mathrm{MC}$ and $\mathrm{EC}$ at concentrations well below those reported previously. The limit of detection (LOD) and the limit of quantification (LOQ) were defined as the analyte concentration corresponding to a signal/noise ratio of 3 and 10 in the control food, in which MC and EC were not detected. The LODs in this study were $0.11 \mu \mathrm{g} / \mathrm{kg}$ for $\mathrm{MC}$, and $0.12 \mu \mathrm{g} / \mathrm{kg}$ for EC, and the LOQs were $0.35 \mu \mathrm{g} / \mathrm{kg}$ for $\mathrm{MC}$ and $0.38 \mu \mathrm{g} / \mathrm{kg}$ for EC using a $2.0 \mathrm{~g}$ sample. Table 1 compares various analytical methods for determining the MC and EC in fermented food and beverages. The method permits the determination of two analytes below that detected previously using the GC-MS method, which was otherwise slightly higher than GC-HRMS or GC-MS/MS methods.

The calibration curves of the MC and EC were constructed by the reaction and extraction of the spiked food samples. Examination of the standard curve by computing a regression line of the peak area ratios for the MC and EC to the internal standard on concentrations using a least-squares fit demonstrated a linear relationship with correlation coefficients of 0.998 and 0.996, respectively. The line of best fit for the $\mathrm{MC}$ was $\mathrm{y}=$ $4.191 \mathrm{x}-0.0001$ over a range of $1.0-100 \mu \mathrm{g} / \mathrm{kg}$ and that for $\mathrm{EC}$ was $\mathrm{y}=13.46 \mathrm{x}+0.0051$ over a range of 1.0-100 $\mu \mathrm{g} / \mathrm{kg}$, where $\mathrm{x}$ is the analyte concentration $(\mathrm{mg} / \mathrm{kg})$ and $y$ is the peak area ratio of the analyte to the internal standard.

The accuracy can be assessed by determining the recovery in spiked samples: Intra-day accuracy was evaluated using five spiked samples at concentrations of 0.05 and $0.002 \mu \mathrm{g} / \mathrm{kg}$ for MC and EC, respectively. The interday accuracy was determined using the sample recovery on three different days. The accuracy was in range of approximately 90 - to $109 \%$ and the precision of the assay was less than $12 \%$, as shown in Table 2 .

\section{Food analysis}

This paper was designed to describe a method to detect $\mathrm{MC}$ and EC in solid and liquid state matrices using GCMS. Generally, many traditional Korean foods are made through fermentation of a mixture of various food materials, and therefore these foods have complicated matrix properties. When the proposed method was applied to the food items, interfering peaks were not observed in the chromatograms near the retention times of the analytes.

Using the proposed method, the levels of $\mathrm{MC}$ and $\mathrm{EC}$ were analyzed in sixteen traditional fermented Korean foods, including soybean paste, red pepper paste, and soy sauce, and eleven beverages and the results were shown in Table 3. MC was detected in a range from 0.4 to $0.8 \mu \mathrm{g} / \mathrm{L}$ in mainly fruit liquors. Most samples had detectable levels of EC in a range from 0.4 to $85.8 \mu \mathrm{g} / \mathrm{L} \mathrm{or} \mu \mathrm{g} / \mathrm{kg}$. The concentration range of the EC of each food or beverage type was found for soybean paste $(0.9-2.7 \mu \mathrm{g} / \mathrm{kg})$, red pepper paste $(0.7-2.3 \mu \mathrm{g} / \mathrm{kg})$, soy sauce $(0.4-8.9 \mu \mathrm{g} / \mathrm{L})$, and beverages (not detected-85.8 $\mu \mathrm{g} / \mathrm{L}$ ). From the results shown in Table 3, the prolonged mean storage time had no relationship with the detected content of EC.

The correlations between the levels of EC and MC in beverages also correlated well with each another $\left(\mathrm{r}^{2}=0.69, \mathrm{P}=0.001\right)$ due to the similar formation mechanisms. It is suggested that MC is also formed by the reaction of urea with methanol.

Table 3 Analytical results of the NMC and EC in fermented food and beverages

\begin{tabular}{|c|c|c|c|c|c|}
\hline \multirow[t]{2}{*}{ Sample } & \multirow[t]{2}{*}{ State } & \multirow[t]{2}{*}{$\begin{array}{l}\text { Storage } \\
\text { time (yr) }\end{array}$} & \multirow[t]{2}{*}{ Unit } & \multicolumn{2}{|c|}{$\begin{array}{c}\text { Measured } \\
\text { Conc }(\mu \mathrm{g} / \mathrm{kg})\end{array}$} \\
\hline & & & & MC & EC \\
\hline Red pepper paste-1 & Solid & 4 & $\mu \mathrm{g} \mathrm{kg}^{-1}$ & nd & 0.7 \\
\hline Red pepper paste-2 & Solid & 3 & $\mu \mathrm{gg}^{-1}$ & nd & 1.3 \\
\hline Red pepper paste-3 & Solid & 3 & $\mu \mathrm{g} \mathrm{kg}^{-1}$ & nd & 1.9 \\
\hline Red pepper paste-4 & Solid & 2 & $\mu g \mathrm{~kg}^{-1}$ & nd & 1.8 \\
\hline Red pepper paste-5 & Solid & 1 & $\mu g \mathrm{~kg}^{-1}$ & nd & 2.3 \\
\hline Red pepper paste-6 & Solid & 1 & $\mu g \mathrm{~kg}^{-1}$ & nd & 0.9 \\
\hline Soybean paste-1 & Solid & 4 & $\mu \mathrm{kg}^{-1}$ & nd & 0.9 \\
\hline Soybean paste-2 & Solid & 3 & $\mu \mathrm{g} \mathrm{kg}^{-1}$ & nd & 1.5 \\
\hline Soybean paste-3 & Solid & 2 & $\mu \mathrm{g} \mathrm{kg}^{-1}$ & nd & 1.2 \\
\hline Soybean paste-4 & Solid & 4 & $\mu \mathrm{g} \mathrm{kg}^{-1}$ & nd & 1.7 \\
\hline Soy sauce-1 & Liquid & 2 & $\mu g L^{-1}$ & nd & 1.3 \\
\hline Soy sauce-2 & Liquid & 1 & $\mu g L^{-1}$ & nd & 0.4 \\
\hline Soy sauce-3 & Liquid & 1 & $\mu g L^{-1}$ & 0.4 & 8.9 \\
\hline Soy sauce-4 & Liquid & 1 & $\mu g L^{-1}$ & nd & 1.8 \\
\hline Soy sauce-5 & Liquid & 1 & $\mu g L^{-1}$ & nd & 0.8 \\
\hline Soy sauce-6 & Liquid & 1 & $\mu g L^{-1}$ & nd & 1.3 \\
\hline Beer & Liquid & - & $\mu g L^{-1}$ & nd & 3.9 \\
\hline Soju(white distilled liquor) & Liquid & - & $\mu g L^{-1}$ & nd & 4.8 \\
\hline Jeongjong(refined rice wine) & Liquid & - & $\mu g L^{-1}$ & 0.5 & 8.3 \\
\hline Soju(distilled liquor) & Liquid & - & $\mu g L^{-1}$ & nd & nd \\
\hline Makgeolli(raw rice wine)-1 & Liquid & - & $\mu g L^{-1}$ & nd & nd \\
\hline Makgeolli(raw rice wine)-2 & Liquid & - & $\mu g L^{-1}$ & 0.5 & 6.9 \\
\hline Makgeolli(raw rice wine)-3 & Liquid & - & $\mu g L^{-1}$ & nd & 6.0 \\
\hline Fruit liquor-1 & Liquid & - & $\mu g L^{-1}$ & nd & 4.1 \\
\hline Fruit liquor-2 & Liquid & - & $\mu g L^{-1}$ & 0.6 & 78.7 \\
\hline Fruit liquor-3 & Liquid & - & $\mu g L^{-1}$ & 0.7 & 68.6 \\
\hline Fruit liquor-4 & Liquid & - & $\mu g L^{-1}$ & 0.8 & 85.8 \\
\hline
\end{tabular}




\section{Conclusions}

In this paper, a simple, sensitive method to detect $\mathrm{MC}$ and EC in several solid foods and liquid foods is presented based on derivatization with 9-xanthydrol for 10 min at an ambient temperature. Using $2.0 \mathrm{~g}$ for solid food and liquid food, the LODs of the MC and EC were 0.11 and $0.12 \mu \mathrm{g} / \mathrm{kg}$, respectively, and the LOQs of the $\mathrm{MC}$ and EC were 0.35 and $0.38 \mu \mathrm{g} / \mathrm{kg}$, respectively. The accuracy and precision of the assay were acceptable: the relative standard deviation was less than $12 \%$. The concentrations of MC and EC in Korean traditional fermented foods were measured to be to $85.8 \mu \mathrm{g} / \mathrm{kg}$. The natural levels of $\mathrm{MC}$ and $\mathrm{EC}$ found in these foods are not considered to pose a risk to human health.

\section{Competing interests}

The authors declare that they have no competing interests.

\section{Authors' contributions}

HSS initiated and prepared the draft. EYY conducted the extraction and method developments. All authors designed the study. All authors contributed to data analyses and to finalizing the manuscript. Both authors have read and approved the final version.

\section{Author details}

'Department of Environmental Education, Kongju 314-701, Republic of Korea. ${ }^{2}$ Department of Environmental Science, Kongju National University, Kongju 314-701, Republic of Korea.

Received: 28 September 2012 Accepted: 10 December 2012 Published: 13 December 2012

\section{Reference}

1. Nout MJR: Fermented foods and food safety. Food Res Int 1994, 27:291-298.

2. Weber JV, Sharypov VI: 009. Ethyl carbamate in foods and beverages: a review. Environ Chem Lett 2009, 7:233-247.

3. IARC (International Agency for Research on Cancer): Alcoholic beverage consumption and ethyl carbamate (urethane), international agency for research. 96th edition. Geneva: World Health Organization; 2007. Available from URL: http://monographs.iarc.fr/ENG/Monographs/vol96/index.php. Accessed 15 August 2012.

4. EUR-Lex: Commission recommendation of 2 march 2010 on the prevention and reduction of ethyl carbamate contamination in stone fruit spirits and stone fruit marc spirits and on the monitoring of ethyl carbamate levels in these beverages. Off J Eur Uni 2010, 53:53-57.

5. Funch F, Lisbjerg S: Analysis of ethyl carbamate in alcoholic beverages. Lebens Wissen Technol 1988, 186:29-32.

6. Kim YK, Lee KE, Chung HJ: Determination of ethyl carbamate in some fermented Korean foods and beverages. Food Addit Contam 2000, 17:469-475

7. Foureman P, Mason JM, Valencia R, Zimmering S: Chemical mutagenesis testing in drosophila. Environ Mol Mutagen 1994, 23:51-63.

8. $\mathrm{NIH}$ (National Institutes of Health): U.S. Department of health and human services public health service, toxicology and carcinogenesis studies of methyl carbamate in rats and mice.; 1987. U.S. DEPARTMENT OF HEALTH AND HUMAN SERVICES, Public Health Service National Institutes of Health, NIH Publication No.88-2584, http://ntp.niehs.nih.gov/ntp/htdocs/lt_rpts/tr328.pdf.

9. Sen NP, Seaman SW, Weber D: A method for the determination of methyl carbamate and ethyl carbamate in wines. Food Addit Contam 1992, 9:149-160.

10. Herbert P, Santos L, Bastos M, Barros M, Alves A: New HPLC method to determine ethyl carbamate in alcoholic beverages using fluorescence detection. J Food Sci 2002, 67:1616-1625.

11. Fu ML, Liu J, Chen QH: Determination of ethyl carbamate in Chinese yellow rice wine using high-performance liquid chromatography with fluorescence detection. Int J Food Sci Technol 2010, 45:1297-1302.

12. Madrera RR, Valles BS: Determination of ethyl carbamate in cider spirits by HPLC-FLD. Food Control 2009, 20:139-143.
13. Deak E, Gyepes A, Stefanovits-Banyai E: Determination of ethyl carbamate in palinka spirits by liquid chromatography-electrospray tandem mass spectrometry after derivatization. Food Res Int 2010, 43:2452-2455.

14. Ye CW, Zhang XN, Gao YL: Multiple headspace solid-phase microextraction after matrix modification for avoiding matrix effect in the determination of ethyl carbamate in bread. Anal Chim Acta 2012, 710:75-80.

15. Ye CW, Zhang XN, Huang JY: Multiple headspace solid-phase microextraction of ethyl carbamate from different alcoholic beverages employing drying agent based matrix modification. J Chromatogr A 2011, 1218:5063-5070.

16. Ballesteros E, Gallego M, Valcarcel M: Automatic determination of Nmethylcarbamate pesticides by using a liquid-liquid extractor derivatization module coupled on-line to a gas chromatograph equipped with a flame ionization detector. J Chromatogr 1993, 633:169-176.

17. Ya-Ping M, Fu-Quan D, Dai-Zhou C: Determination of ethyl carbamate in alcoholic beverages by capillary multi-dimensional gas chromatography with thermionic specific detection. J Chromatogr A 1995, 695:259-265.

18. Baffa Junior JC, Mendonca RC, Pereira JM: Ethyl-carbamate determination by gas chromatography-mass spectrometry at different stages of production of a traditional Brazilian spirit. Food Chem 2011, 129:1383-1387.

19. Hong KP, Kang YS, Jung DC: Exposure to ethyl carbamate by consumption of alcoholic beverages imported in Korea. Food Sci Biotechnol 2007, 16:975-980.

20. Wai-Cheung CS, Ping KK, Ling-Sze CB: Determination of ethyl carbamate in fermented foods by GC-HRMS. Chromatographia 2010, 72:571-575.

21. Lachenmeier DW, Frank W, Kuballa T: Application of tandem mass spectrometry combined with gas chromatography to the routine analysis of ethyl carbamate in stone-fruit spirits. Rapid Commun Mass Sp 2005, 19:108-112.

22. Lachenmeier DW, Nerlich U, Kuballa T: Automated determination of ethyl carbamate in stone-fruit spirits using headspace solid-phase microextraction and gas chromatography-tandem mass spectrometry. J Chromatogr A 2006, 1108:116-120.

23. Whiton RS, Zoecklein BW: Determination of ethyl carbamate in wine by solid-phase microextraction and gas chromatography/mass spectrometry. Am J Enol Viticult 2002, 53:60-63.

24. Woo IS, Kim IH, Yun UJ: An improved method for determination of ethyl carbamate in Korean traditional rice wine. J Ind Microbiol Biot 2001, 26:363-368.

25. Fauhl C, Catsburg R, Wittkowski R: Determination of ethyl carbamate in soy sauces. Food Chem 1993, 48:313-316.

26. Giachetti C, Assandri A, Zanolo G: Gas chromatographic-mass spectrometric determination of ethyl carbamate as the xanthylamide derivative in Italian aqua vitae (grappa) samples. J Chromatogr 1991, 585:111-115.

27. Lei FF, Zhang XN, Gao YL: Multiple headspace solid-phase microextraction using a new fiber for avoiding matrix interferences in the quantitative determination of ethyl carbamate in pickles. J Sep Sci 2012, 35:1152-1159.

28. Ubeda C, Balsera C, Troncoso AM: Validation of an analytical method for the determination of ethyl carbamate in vinegars. Talanta 2012, 89:178-182.

\section{doi:10.1186/1752-153X-6-157}

Cite this article as: Shin and Yang: Simultaneous determination of methylcarbamate and ethylcarbamate in fermented foods and beverages by derivatization and GC-MS analysis. Chemistry Central Journal 2012 6:157. 